\title{
Sociodemographic Determinants of Caesarean Delivery in the Largest Public Maternity Hospital in Angola
}

\author{
Determinantes Sociodemográficos do Parto por \\ Cesariana na Maior Maternidade Pública de Angola
}

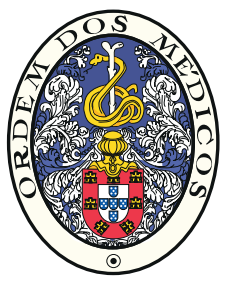

Tazi NIMI $\triangle 1,3$, Diogo COSTA 1,2, Paulo CAMPOS $^{3}$, Henrique BARROS
Acta Med Port 2019 Jun;32(6):434-440 - https://doi.org/10.20344/amp.10409

\section{ABSTRACT}

Introduction: This study aimed to describe demographic, socioeconomic and pregnancy-related characteristics associated with a caesarean delivery in Luanda.

Material and Methods: We conducted a cross-sectional study which included 995 puerperal women and who were assessed between December 2012 and February 2013 at Lucrécia Paím maternity hospital in Luanda, Angola. Data was collected using a structured questionnaire administered by trained interviewers. Logistic regression models were fitted to estimate the magnitude of associations (odds ratios-95\% confidence intervals) between the type of delivery and variables showing a significant association in the bivariate analysis. Results: The prevalence of caesarean section was $44 \%$. Women with caesarean delivery were less educated, resided more often in a periurban area and were more likely to disclose lower family income when compared with women who had vaginal delivery. Living in a periurban area was significantly associated with a caesarean delivery regardless of all covariates considered, for primiparous women (adjusted odds ratios, 95\% confidence intervals $=2.14,1.27-3.62$ ) and for multiparous women $(1.78,1.26-2.51)$. Among multiparous women, a lower family income was also significantly associated with caesarean delivery. Hypertensive disorders during the current pregnancy were associated with a caesarean delivery in the multivariate models fitted for primiparous $(3.96,1.57-9.98)$ and for multiparous women $(1.68,1.03-2.74)$.

Discussion: The associations between low socioeconomic position and high risk of caesarean delivery demonstrated in this study are consistent results in previous researches curried out in African contexts. The poorer and less educated women, who live far from health facilities, have few antenatal care visits and often arrive with complicated conditions, justifying a caesarean delivery. Lack of qualified human and material resources to manage emergencies in peripheral health centers and delaying in the reference system also leads to an increase in the number of caesareans performed in this particular maternity hospital.

Conclusion: Sociodemographic differences were observed according to the type of delivery. Cesarean section was more prevalent among women with lower income and residents in periurban areas.

Keywords: Angola; Cesarean Section; Socioeconomic Factors

\section{RESUMO}

Introdução: Este estudo teve como objetivo descrever as características socioeconómicas e demográficas associadas ao parto por cesariana em Angola.

Material e Métodos: Estudo transversal que incluiu 995 participantes puérperas no período compreendido entre dezembro de 2012 a fevereiro de 2013 na Maternidade Lucrécia Paím, em Luanda, Angola. A informação foi recolhida através de um questionário estruturado aplicado por entrevistadores treinados. Foi utilizada regressão logística para estimar a magnitude da associação (odds ratios - intervalos de confiança a 95\%) entre o tipo de parto e as covariáveis.

Resultados: A prevalência de cesariana neste estudo foi de $44 \%$. As mulheres que fizeram cesariana eram menos escolarizadas, residiam mais frequentemente em zonas periurbanas e com rendimentos mais baixos quando comparadas com as mulheres que tiveram parto vaginal. Residir numa área periurbana estava significativamente associado ao parto por cesariana independentemente de outros fatores, (odds ratios ajustado para mulheres primíparas, intervalos de confiança 95\% $=2,14,1,27-3,62)$ e mulheres multíparas $(1,78$, 1,26 - 2,51). Hipertensão durante a gravidez atual associou-se ao parto por cesariana tanto em primíparas $(3,96 ; 1,57-9,98)$ como em multíparas $(1,68 ; 1,03-2,74)$.

Discussão: As associações entre baixa posição socioeconómica e o alto risco de cesariana demonstradas neste estudo são resultados consistentes em pesquisas prévias realizadas em contextos africanos. As mulheres mais pobres e menos instruídas, que residem longe das unidades de saúde, têm poucas consultas pré-natais e muitas vezes chegam com condições complicadas, justificando um parto por cesariana. A falta de recursos humanos e materiais qualificados para gestão de emergências em centros de saúde periféricos e o atraso no sistema de referência também leva a um aumento no número de cesarianas realizadas nesse hospital particular.

Conclusão: Foram observadas diferenças sociodemográficas de acordo com o tipo de parto. O parto por cesariana foi mais frequente entre mulheres com rendimentos mais baixo e residentes em áreas periurbanas.

Palavras-chave: Angola; Cesariana; Factores Socioeconómicos

\section{INTRODUCTION}

A report from the Millennium Development Goals (MDGs) shows that, between 1990 and 2015, the maternal

mortality rate has declined by $45 \%$ worldwide, and $49 \%$ in sub-Saharan Africa. ${ }^{1}$

\footnotetext{
1. Institute of Public Health. University of Porto. Porto. Portugal.

2. Department of Clinical Epidemiology, Predictive Medicine and Public Health. Medical School. University of Porto. Porto. Portugal.

3. Faculdade de Medicina. Universidade Agostinho Neto. Luanda. Angola.

$\triangle$ Autor correspondente: Tazi Nimi. tznimi@yahoo.com.br

Recebido: 14 de fevereiro de 2018 - Aceite: 14 de janeiro de 2019 | Copyright @ Ordem dos Médicos 2019
} 
Despite that, the sharp increase in caesarean rates in the last decades, especially in low and middle-income countries, ${ }^{2,3}$ exceeding the upper limit proposed by the World Health Organization (WHO) $(10 \%-15 \%)$ has become a public health problem worldwide. ${ }^{4}$ Unnecessary caesarean sections result in avoidable suffering and wasted health care resources from unduly allocated staff, surgical procedures and longer hospital stays. ${ }^{5}$ Previous studies showed that in developing countries, caesarian sections have increased among women from the richest classes, ${ }^{6}$ although in developed countries this increase was observed among poor and less educated women. ${ }^{7}$

Although some well-established clinical indicators of caesarean sections are available, non-clinical factors often become key elements in decision-making. At the basis of such a decision is the encounter between the woman and her caregiver, in which the woman's preferences and views regarding childbirth and the clinician's subjective interpretation of her obstetric risks and the perception of the desired mode of delivery are likely to influence the decision to proceed with a caesarean. ${ }^{8} \mathrm{~A}$ large body of research has shown a clear association between caesarean rates and socioeconomic factors apart from the woman's obstetric risk even where access to health care services is not an issue..$^{9,10}$ These findings suggest that a woman's preference or her ability to engage in the decision-making process concerning the mode of delivery, are likely shaped by her socioeconomic context.

Since the independence of Angola, in 1992, the National Health System was created based on equity, universality and gratuity. ${ }^{11}$ Moreover, National Health System care in Angola includes 2356 units, of which 1981 primary health care centres, 210 hospitals and 43 maternal and child health centers. ${ }^{12}$ According to the Inquérito de Indicadores Múltiplos (IIMS) of Angola, $82 \%$ of women with one child born alive in the five years prior to the survey received pre-natal consultation. Nearly half of births (46\%) occurred in a health facility $(44 \%$ in the public sector and $2 \%$ in the private sector). Nevertheless, more than half of births (53\%) occurred outside the hospital with no medical assistance. ${ }^{11,13}$

However, there is a lack of studies focused on maternal health in the African context. Therefore, the aim of this study was to describe demographic, socioeconomic and pregnancy-related characteristics associated with a caesarean delivery in the largest maternity hospital of Luanda, Angola.

\section{MATERIAL AND METHODS Setting}

A cross-sectional study conducted in the public Lucrécia Paím Maternity Hospital (MLP) located in Luanda (Angola), a national reference centre for maternal health care and also for research and training of future healthcare professionals. As a tertiary health facility, the maternity hospital is dedicated to the most complicated cases referred from other health facilities in lower levels of care. The maternity hospital performs an average of 100 deliveries per day. It performs caesarean deliveries, has intensive care units for both women and newborns, has specialized areas for complicated pregnancies or puerperal women and has on site laboratory support. According to the hospital's internal records, during the study period (December 2012 to February 2013), there were 5442 deliveries in this hospital, of which 1686 were caesarean deliveries and 3756 vaginal deliveries.

\section{Participants}

Recruitment of participants occurred from December 2012 to February 2013. Women were invited to participate in the study after delivery and before hospital discharge. Women having a vaginal delivery were usually discharged after 6 hours and women undergoing caesarean delivery have a longer stay, from 3 to 7 days. Women having a vaginal delivery remained in two specific rooms of the maternity ward where trained staff introduced the study's aims. Women having a caesarean delivery remained in a separate ward and received the same invitation. Invitations occurred mainly during daytime (from 8 a.m. to 5 p.m.), and women were visited in specific days of the week, according to the delivery type, to maximize chances of recruitment: Mondays, Wednesdays and Fridays for vaginal deliveries and Tuesdays and Thursdays for caesarean section.

Exclusion criteria were severe conditions complicating delivery (e.g. eclampsia/ pre-eclampsia, complicated malaria, post-partum haemorrhage), foreign nationality, residency in Luanda for less than six months and twin pregnancy. Data was collected by face to face interviews using a structured questionnaire administered by six trained interviewers (three males and three females). Written or verbal informed consent (according to the women's literacy) was obtained from all participants.

The questionnaire comprised a total of 77 questions assessing demographic and socioeconomic characteristics, medical and gynaecological history, history of present pregnancy, prenatal care, nutrition, smoking and alcohol consumption. Variables related to hospital admission, delivery and newborn data were drawn from the clinical charts. During the recruitment period, 1040 women meeting criteria were invited to participate. Of these, 40 refused participation and 5 had missing information in their clinical files. Thus, for the present study, a total of 995 participants were considered.

As a strategy to involve women, the research team gave bed nets after completing the questionnaire, which was sponsored by the National Program Against Malaria. The project was approved by the Ethics Committee of the Faculty of Medicine of the University Agostinho Neto.

\section{Outcomes and covariates}

The study outcome was the mode of delivery, categorized as vaginal or caesarean. The following variables were considered potential sociodemographic determinants of the mode of delivery: maternal age (categorized in $<18$, $18-34$ and $\geq 35$ years old); completed years of school $(<9$, $9-12$ and $>12$ ); marital status (married or in cohabitation and single); residency in an urban (Luanda municipality) or 
periurban area (municipalities outside Luanda, specifically Viana, Cazenga, Belas, Cacuaco, Icolo E Bengo and Kissama); current household income per month (<100; $100-300$ and $>300$ USD or other that includes those women who do not know/ prefer not to disclose). Smoking during pregnancy was recorded as "yes or no" and alcohol consumption according to the question "Have you taken any type of alcoholic beverage during this pregnancy?" (yes, no).

The following variables related to current pregnancy and antenatal care were considered: year of the first sexual contact ( $<15$ years old, $\geq 15$ or does not know); first antenatal care visit (first trimester, second trimester, third trimester); frequency of antenatal care visits $(1,2-4, \geq 5)$; hospitalization during pregnancy (yes or no); satisfaction with antenatal care (rated in a 5 point scale further dichotomized in $\geq 3$ as "satisfied" and $<3$ as unsatisfied); type of antenatal care (only public services or at least one visit to a private doctor or service); complication or diseases during current pregnancy (hypertension, malaria, urinary infections, haemorrhage and threat of abortion).

The number of previous pregnancies was considered for the coding of two variables categorizing women according to history of caesarean (primiparous, multiparous with no previous caesarean and multiparous with at least one previous caesarean) and according to history of pregnancy complications, i.e., self-reported history of diabetes, hyper- tension, urinary infection or hemorrhage (primiparous, multiparous with no history of complications and multiparous with previous complications).

\section{Statistical analysis}

Analysis of data was performed with SPSS 21. Chisquare or Fisher exact tests were used to compare the prevalence of vaginal deliveries and caesarean sections according to demographic, socioeconomic, lifestyle, reproductive health related characteristics and pregnancy complications.

Logistic regression models were fitted to estimate the magnitude of associations [odds ratios (OR), 95\% confidence $(\mathrm{Cl})$ ] between the type of delivery (vaginal versus caesarean) and variables showing a significant association in the bivariate analysis. Models were fitted separately for primiparous and for multiparous and adjusted for potential confounders.

\section{RESULTS}

In our study, the prevalence of caesarean section was $44 \%$. Table 1 shows the characteristics studied in our population according to the type of delivery (vaginal and caesarean). Women with caesarean delivery were less educated, resided more often in a periurban area and were more likely to disclose lower family income when compared with women who had vaginal delivery.

Table 1 - Participants characteristics' according to type of delivery

\begin{tabular}{|c|c|c|c|}
\hline & $\begin{array}{r}\text { Vaginal } \\
n=560 \\
n(\%)\end{array}$ & $\begin{array}{r}\text { Cesarean } \\
n=435 \\
n(\%)\end{array}$ & $p$-value* \\
\hline \multicolumn{4}{|l|}{ Sociodemographic characteristics } \\
\hline $\begin{array}{l}\text { Maternal age (years) } \\
\quad<18 \\
18-34 \\
\geq 35 \\
\text { No information }\end{array}$ & $\begin{array}{r}65(11.6) \\
431(77.1) \\
653(11.3) \\
2\end{array}$ & $\begin{array}{r}40(9.2) \\
327(75.3) \\
67(15.4)\end{array}$ & 0.096 \\
\hline $\begin{array}{l}\text { Education (years) } \\
\qquad \begin{array}{l}<9 \\
9-12 \\
\geq 12 \\
\text { No information }\end{array}\end{array}$ & $\begin{array}{r}255(45.9) \\
240(43.2) \\
60(10.8) \\
8\end{array}$ & $\begin{array}{r}249(57.6) \\
141(32.6) \\
42(9.7)\end{array}$ & 0.001 \\
\hline $\begin{array}{l}\text { Marital status } \\
\text { Married (or in cohabitation) } \\
\text { Single }\end{array}$ & $\begin{array}{l}417(74.5) \\
143(25.5)\end{array}$ & $\begin{array}{r}347(79.8) \\
88(20.2)\end{array}$ & 0.059 \\
\hline $\begin{array}{l}\text { Place of residence } \\
\text { Urban } \\
\text { Periurban } \\
\text { No information }\end{array}$ & $\begin{array}{r}328(58.9) \\
229(41.1) \\
6\end{array}$ & $\begin{array}{l}178(41.2) \\
254(58.8)\end{array}$ & $<0.001$ \\
\hline $\begin{array}{l}\text { Household income (dollars) } \\
<100 \\
100-300 \\
>300 \\
\text { Do not know/ prefers not to disclose } \\
\text { No information }\end{array}$ & $\begin{array}{r}34(6.2) \\
128(23.4) \\
175(32.1) \\
209(38.3) \\
27\end{array}$ & $\begin{array}{r}50(11.8) \\
126(29.9) \\
112(26.5) \\
134(31.8)\end{array}$ & 0.001 \\
\hline $\begin{array}{l}\text { Previous pregnancies and caesarean } \\
\text { Primiparous } \\
\text { Multiparous no c-section } \\
\text { Multiparous previous c-section }\end{array}$ & $\begin{array}{r}160(28.6) \\
351(62.7) \\
49(8.8)\end{array}$ & $\begin{array}{l}121(27.8) \\
170(39.1) \\
144(33.1)\end{array}$ & $<0.001$ \\
\hline
\end{tabular}


Table 1 (cont.) - Participants characteristics' according to type of delivery

\begin{tabular}{|c|c|c|c|}
\hline & $\begin{array}{r}\text { Vaginal } \\
n=560 \\
n(\%)\end{array}$ & $\begin{array}{r}\text { Cesarean } \\
n=435 \\
n(\%)\end{array}$ & $p$-value* \\
\hline \multicolumn{4}{|c|}{$\begin{array}{l}\text { Previous pregnancies and complications during last } \\
\text { pregnancy† }\end{array}$} \\
\hline Primiparous & $160(28.6)$ & $121(27.8)$ & 0.026 \\
\hline Multiparous no previous complication & $297(53.0)$ & $204(46.9)$ & \\
\hline Multiparous with previous complication & $103(18.4)$ & $110(25.3)$ & \\
\hline \multicolumn{4}{|l|}{ Place of antenatal visits } \\
\hline Private & $60(10.8)$ & $45(10.5)$ & 0.982 \\
\hline Public & $496(89.2)$ & $382(89.5)$ & \\
\hline No information & 12 & & \\
\hline \multicolumn{4}{|l|}{ 1st sexual contact (Age) } \\
\hline$<15$ & $52(9.3)$ & $47(10.8)$ & 0.189 \\
\hline$\geq 15$ & $476(85.2)$ & $353(81.1)$ & \\
\hline Does not know & $31(5.5)$ & $35(8.0)$ & \\
\hline No information & 1 & & \\
\hline \multicolumn{4}{|l|}{ Satisfaction in antenatal care } \\
\hline No & $42(7.7)$ & $17(4.0)$ & 0.022 \\
\hline Yes & $504(92.3)$ & $413(96.0)$ & \\
\hline No information & 19 & & \\
\hline \multicolumn{4}{|l|}{ First antenatal care visit } \\
\hline 1st trimester & $280(52.3)$ & $218(52.4)$ & 0.831 \\
\hline 2nd trimester & $233(43.6)$ & $184(44.2)$ & \\
\hline 3rd trimester & $22(4.1)$ & $14(3.4)$ & \\
\hline No information & 44 & & \\
\hline \multicolumn{4}{|l|}{ Frequency of antenatal care visits } \\
\hline$<2$ & $31(5.8)$ & $23(5.8)$ & 0.262 \\
\hline $2-4$ & $299(55.5)$ & $200(50.3)$ & \\
\hline$\geq 5$ & $209(38.8)$ & $175(44.0)$ & \\
\hline No information & 58 & & \\
\hline \multicolumn{4}{|l|}{ Hospitalization during pregnancy } \\
\hline No & $526(93.9)$ & $394(90.6)$ & 0.062 \\
\hline Yes & $34(6.1)$ & $41(9.4)$ & \\
\hline \multicolumn{4}{|l|}{ Current pregnancy complications } \\
\hline \multicolumn{4}{|l|}{ Malaria } \\
\hline No & $455(81.2)$ & $363(83.4)$ & 0.415 \\
\hline Yes & $105(18.8)$ & $72(16.6)$ & \\
\hline \multicolumn{4}{|l|}{ Urinary infection } \\
\hline No & $356(63.6)$ & $293(67.4)$ & 0.239 \\
\hline Yes & $204(36.4)$ & $142(32.4)$ & \\
\hline \multicolumn{4}{|l|}{ Haemorrhage } \\
\hline No & $527(94.1)$ & $413(94.9)$ & 0.666 \\
\hline Yes & $33(5.9)$ & $22(5.1)$ & \\
\hline Hypertensive disorders & & $364(89.7)$ & 0.004 \\
\hline No & $504(90.0)$ & $71(16.3)$ & \\
\hline Yes & $56(10.0)$ & & \\
\hline \multicolumn{4}{|l|}{ Threatened abortion } \\
\hline No & $533(95.2)$ & $418(96.1)$ & 0.589 \\
\hline Yes & $27(4.8)$ & $17(3.9)$ & \\
\hline \multicolumn{4}{|l|}{ Lifestyle } \\
\hline \multicolumn{4}{|l|}{ Smoking } \\
\hline No & $559(99.8)$ & $433(99.5)$ & 0.584 \\
\hline Yes & $1(0.2)$ & $2(0.5)$ & \\
\hline \multicolumn{4}{|l|}{ Alcohol consumption } \\
\hline No & $463(82.7)$ & $346(79.5)$ & 0.239 \\
\hline Yes & $97(17.3)$ & $89(20.5)$ & \\
\hline
\end{tabular}

${ }^{*}$ chi-square test; †diseases or complications during the last pregnancy (categorized in yes or no, if the woman has been diagnosed with any of the following: diabetes, hypertension, urinary infection, hemorrhage or complications from obstetric causes including placenta praevia, open cervix and threat of abortion). 
Regarding the characteristics related to the previous pregnancy, current pregnancy and antenatal care, we found that $33 \%$ of women with a caesarean delivery were multiparous with a history of previous caesarean while this proportion was $9 \%$ among women with a vaginal delivery. Also, $25 \%$ of women with a caesarean delivery and $18 \%$ of women with vaginal delivery reported previous pregnancy complications. Overall, few women reported dissatisfaction with the antenatal care provided, less frequent among women with a caesarean delivery compared to women with a vaginal delivery $(4 \%$ vs $8 \%$, respectively, $p=0.022)$. No statistically significant differences were observed between vaginal and caesarean deliveries according to the place, frequency and time of first antenatal care visits, nor according to hospitalization during pregnancy.

According to the complications assessed during the current pregnancy, we observed a higher proportion of hypertensive disorders women among those with a caesarean delivery compared to vaginal deliveries (16\% vs $10 \%$, $p=0.004)$. We did not find statistically significant differences regarding smoking habits and consumption of alcohol.

Table 2 presents the associations between the type of delivery and the factors that were statistically significant in the bivariate analysis, stratified for primiparous and multiparous women. A periurban residency (versus urban) was significantly associated with a caesarean delivery regardless of all covariates considered, for both primiparous women (adjusted $\mathrm{OR}, 95 \% \mathrm{Cl}=2.14,1.27$ - 3.62) and multiparous women $(1.78,1.26-2.51)$. Hypertensive disorders during the current pregnancy were also significantly associated with a caesarean delivery in the multivariate models fitted for primiparous $(3.96,1.57$ - 9.98) and for multiparous women (1.68, 1.03 - 2.74). Among multiparous women, a family income $<100$ was also significantly associated with caesarean delivery, compared to a family income of $>300$ dollars in the fully adjusted model $(1.90,1.00-3.60)$. As expected, a history of previous caesarean was positively associated with a current caesarean among multiparous women $(5.68,3.82-8.46)$.

\section{DISCUSSION}

The caesarean delivery was highly prevalent in this sample of Angolan women. Moreover, higher rates of caesarean were observed in women with lower family income and living in a periurban area, regardless of parity status and even after additional adjustment for conditions such as hypertension. These results are consistent with previous studies in African contexts, that report associations between a low socioeconomic position and a high risk of caesarean delivery. ${ }^{14}$

We hypothesize that poorer and less educated women, who live far from health facilities, have few antenatal care visits and often arrive with complicated conditions, justifying a caesarean delivery. Furthermore, the lack of qualified human and material resources to manage emergencies in peripheral health centres and the delay in the reference system (which consists of transferring a patient to a higher level health facility with Infrastructures, qualified human resources and equipment for to response) also leads to an increase in the number of caesareans performed in this particular maternity hospital.

A study using data from the most recent DHS survey from countries in Sub-Saharan Africa, South and Southeast Asia, Latin America and the Caribbean from which information on caesarean and the wealth index were available,

Table 2 - Association between sociodemographic characteristics and type of delivery

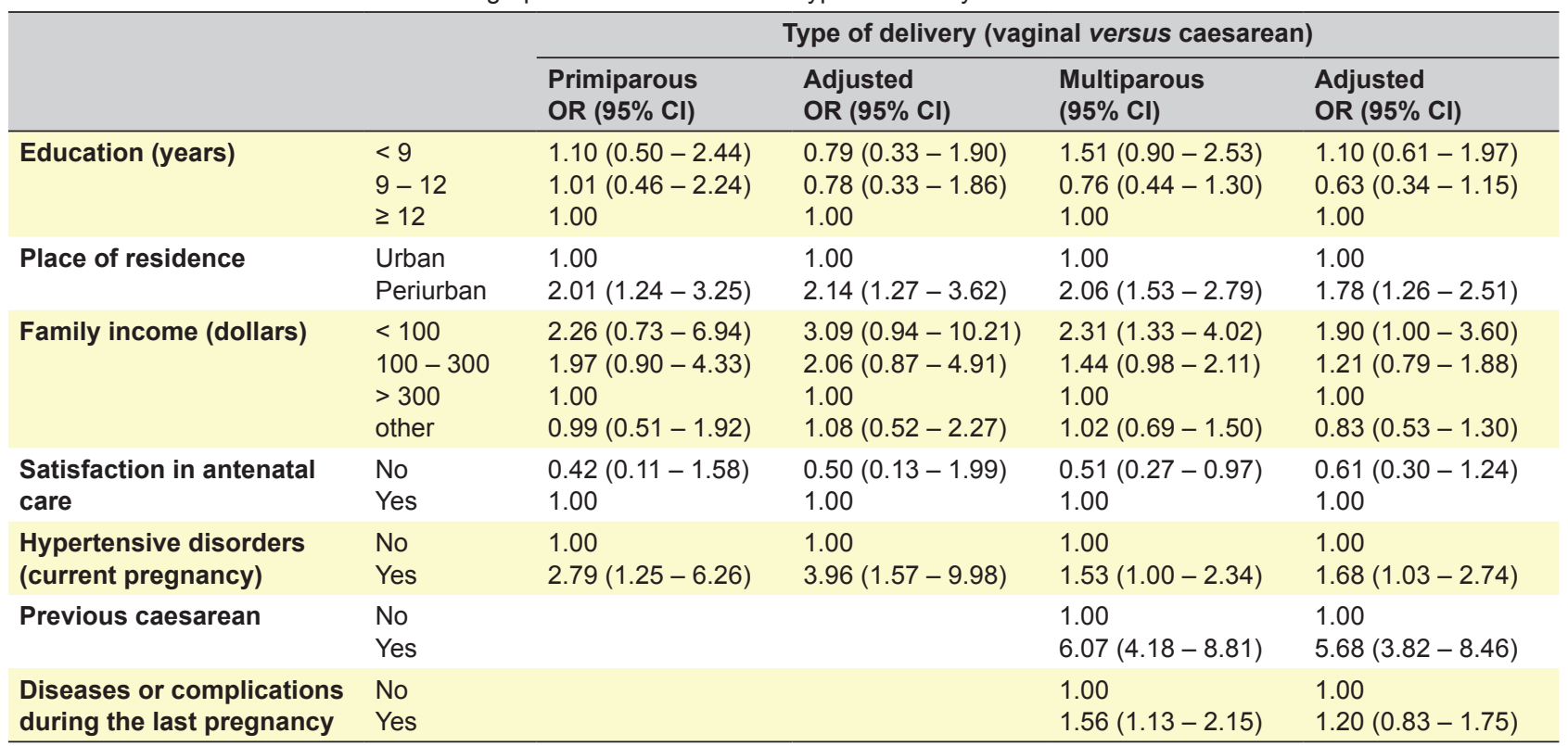

OR $(95 \% \mathrm{Cl})$ : odds ratio (95\% confidence interval); *adjusted for all variables listed except previous caesarean and diseases during last pregnancy; **adjusted for all variables listed; †diseases or complications during the last pregnancy (categorized in yes or no, if the woman has been diagnosed with any of the following: diabetes, hypertension, urinary infection, hemorrhage or complications from obstetric causes including placenta praevia, open cervix and threat of abortion). 
contrasts with our results. It showed that the richest classes have the highest rates of caesarean section. ${ }^{6}$ The expansion of medical indications, such as the liberalization of the threshold for these indications appears to have occurred over time. As a result, an increase in non-medically indicated cesarean sections was noted among the wealthiest. ${ }^{6}$ However, some studies show that in poorer countries, particularly in sub-Saharan Africa, large segments of the population have almost no access to potentially life-saving caesareans and women are likely to die for lack of access to the procedure. ${ }^{6,15}$ In the African context, we should find lower rates of caesarean delivery, because African women often refuse surgery because of fear and the perception of the importance of vaginal delivery that defines womanhood. However, this explanation cannot explain our results regardless of socioeconomic status. ${ }^{16}$

In this study a caesarean delivery was associated with a history of previous caesarean section, with complications in previous pregnancies and with hypertensive disorders in the current pregnancy. A review showed that maternal complications occur in $3 \%-18 \%$ of caesarean rates. ${ }^{17}$ A study done in five low-income countries (Bangladesh, Guinea, Mali, Niger and Uganda), among the indications for a caesarean delivery, previous caesarean ranged between $0.7 \%$ and $18.7 \%$ and severe preeclampsia or eclampsia ranged between $0 \%$ and $11.1 \%{ }^{18}$ In fact, hypertensive disorders during pregnancy induce metabolic changes that lead to a high-risk pregnancy and, consequently a caesarean delivery. ${ }^{19}$

When we analyze the relationship between the type of delivery and the variables that were significant in the bivariate analysis, we found an association between caesarean delivery and place of residence, family income and hypertensive disorders in the current pregnancy in primiparous and in multiparous women. Although several studies show that women living in remote areas with a low income ${ }^{6,15}$ had no access to a caesarean delivery, considered as a means to save lives of both mother and babies, these women do have access to caesarean delivery when referred to this facility. But in many situations, the state in which they arrive to the maternity hospital often leads to the decision to carry out a cesarean delivery.

In this study, the prevalence of caesarean delivery was $44 \%$, which is above what is established by the World Health Organization $(10 \%-15 \%) .{ }^{4}$ Although the literature confirms there is an increase in rates of caesarean sections in middle and high income countries, these figures contrast with the rates found in low-income areas, in particular in Sub-Saharan Africa, where rates tend to be lower than what is established. ${ }^{20}$ In our reality, this maternity hospital is one of the largest in the country, has a large number of qualified staff and receives all cases referred from Luanda and elsewhere. As such, this may justify a higher prevalence of caesarean sections. Additional explanations concern the way recruitment was carried out: women with caesarean deliveries had more time to be surveyed, taking into account their stay in the maternity hospital compared with women who had vaginal deliveries that had only six hours after delivery to be discharged.

As expected, a previous caesarean section was associated with caesarean delivery as described in several studies. A study including medical records of Southeastern Brazil shows caesarean delivery in the current pregnancy was associated with previous caesarean delivery. ${ }^{21}$ The literature reports that women who had a previous cesarean section tend have a higher risk of uterine rupture, placenta previa and placental abruption in their subsequent pregnancies. ${ }^{22}$

Few women in our study who had caesarean delivery were dissatisfied with the antenatal care probably because these women presented some obstetric risk, and therefore they received more medical attention. The literature states that the determinants of satisfaction with antenatal care are too complex to be studied because those include not only clinical factors but also economic and organizational factors, the attitude of the physician in the management of labour, as well as social and cultural attitudes of the woman herself. Satisfaction involves multiple objectives and subjective aspects. ${ }^{23}$

\section{Study limitations}

This is a cross-sectional study, so causality cannot be determined. A selection bias is present, since the maternity hospital is not the typical place to deliver in Angola. Most women give birth at home with the help of traditional birth attendants or experienced women in the community, so our sample does not represent the experience of Angolan women in general, but only those who have a hospital birth. This also means that a large proportion of women, particularly those in a socioeconomically disadvantaged situation, are probably underrepresented. Also, women with severe conditions at delivery and multiple childbirths were excluded during recruitment, which may lead to a selection bias, since could have excluded women with the different socioeconomic profile.

The institutional coverage of births is very low. It is estimated that $69 \%$ of pregnant women visit a health facility at least one time at some point during pregnancy. ${ }^{24}$ Moreover, according to $\mathrm{WHO}$ data in 2012 , only $49 \%$ of births were attended by skilled personnel in Angola. ${ }^{12}$

\section{CONCLUSION}

Sociodemographic differences were observed according to the type of delivery (Appendix 1). Cesarean was more prevalent among women with lower income and residents in periurban areas.

Antenatal care should be available to everyone, and health services in remote areas should have human and material resources in order to provide cesarean deliveries on site, thus avoiding increasing the number of cases.

The improvement of the socioeconomic condition of the population is an aspect to take into account that may benefit the health of this population. Further studies exploring the delivery experience, among women who gave birth at 
home, with no help from a health professional, would contribute to a more comprehensive understanding of maternal health care in the Angolan context.

\section{ACKNOWLEDGEMENTS}

Calouste Gulbenkian Foundation by complement scholarship awarded to students of PALOPs and East Timor.

Government of Angola namely: National Institute of Management Scholarships (INAGBE) by complement Scholarship.

The Faculty of Medicine of the University Agostinho Neto by financial and material support. The Department of Biochemistry of Faculty of Medicine of the University Agostinho Neto, by the laboratory support.

The directors of General and Clinical Lucrécia Paím Maternity where the study was performed.

The National Program to Malaria by technical and material support. The heroic women who agreed to participate in this study.

\section{REFERENCES}

1. UNICEF. The millennium development goals report. New York: United Nations; 2015.

2. Zhao Y, Zhang J, Zamora J, Vogel JP, Souza JP, Jayaratne K, et al., Increases in caesarean delivery rates and change of perinatal outcomes in low- and middle-income countries: a hospital-level analysis of two WHO surveys. Paediatr Perinat Epidemiol. 2017;31:251-62.

3. Betrán AP, Ye J, Moller AB, Zhang J, Gülmezoglu AM, Torloni MR. The increasing trend in caesarean section rates: global, regional and national estimates: 1990-2014. PLoS One. 2016;11:e0148343.

4. World Health Organization. WHO statement on caesarean section rates, 2015. Geneva: WHO; 2015.

5. Betrán AP, Temmerman M, Kingdon C, Mohiddin A, Opiyo N, Torloni $M R$, et al., Interventions to reduce unnecessary caesarean sections in healthy women and babies. Lancet. 2018;392:1358-68.

6. Stanton C, Ronsmans C, Baltimore Group on Cesarean. Recommendations for routine reporting on indications for cesarean delivery in developing countries. Birth. 2008;35:204-11.

7. Tollånes MC, Thompson JM, Daltveit AK, Irgens LM. Cesarean section and maternal education; secular trends in Norway, 1967-2004. Acta Obstet Gynecol Scand. 2007;86:840-8.

8. Nguyen MT, McCullough LB, Chervenak FA. The importance of clinically and ethically fine-tuning decision-making about cesarean delivery. J Perinat Med. 2017;45:551-7.

9. Ye J, Betrán AP, Guerrero Vela M, Souza JP, Zhang J. Searching for the optimal rate of medically necessary cesarean delivery. Birth. 2014;41:237-44.

10. Soto-Vega E, Casco S, Chamizo K, Flores Hernández D, Landini V, Guillén-Florez A. Rising trends of cesarean section worldwide: a systematic review. Obstet Gynecol Int J. 2015;3:00073.

11. Queza AJ. Sistema de saúde em Angola: uma proposta à luz da reforma do serviço nacional de saúde em Portugal. Porto: Universidade do Porto; 2009.

12. World Health Organization. Relatório síntese sobre a situação financeira da saúde em Angola. Tunis: Ministério da Saúde; 2012.

13. Angola, Inquérito de Indicadores Múltiplos e de Saúde (IIMS)

\section{PROTECTION OF HUMANS AND ANIMALS}

The authors declare that the procedures were followed according to the regulations established by the Clinical Research and Ethics Committee and to the Helsinki Declaration of the World Medical Association.

\section{DATA CONFIDENTIALITY}

The authors declare having followed the protocols in use at their working center regarding patients' data publication.

\section{CONFLICTS OF INTEREST}

All authors report no conflict of interest.

\section{FUNDING SOURCES}

This research received no specific grant from any funding agency in the public, commercial, or not-for-profit sectors.

2015-2016. Luanda: Instituto Nacional de Estatística e Ministério da Saúde; 2017.

14. Tavares Hdos P, Tavares SB, Capingana DP, da Gama SG, da Silva LG. Obstetric, sociodemographic, and psychosocial problems of postpartum adolescents of Huambo. Clin Med Insights Womens Health. 2016;9:13-9.

15. Ronsmans C, Holtz S, Stanton C. Socioeconomic differentials in caesarean rates in developing countries: a retrospective analysis. Lancet. 2006;368:1516-23.

16. Shah A, Fawole B, M'imunya JM, Amokrane F, Nafiou I, Wolomby JJ, et al., Cesarean delivery outcomes from the WHO global survey on maternal and perinatal health in Africa. Int $\mathrm{J}$ Gynaecol Obstet. 2009;107:191-7.

17. Dumont A, de Bernis L, Bouvier-Colle MH, Bréart G; MOMA study group Caesarean section rate for maternal indication in sub-Saharan Africa: a systematic review. Lancet. 2001;358:1328-33.

18. Landry E, Pett C, Fiorentino R, Ruminjo J, Mattison C. Assessing the quality of record keeping for cesarean deliveries: results from a multicenter retrospective record review in five low-income countries. BMC Pregnancy Childbirth. 2014;14:139.

19. Penfield CA, Nageotte MP, Wing DA. Disparate rates of cesarean delivery in term nulliparous women with hypertensive disorders of pregnancy. Am J Perinatol. 2019.

20 .Balachandran L, Vaswani PR, Mogotlane R. Pregnancy outcome in women with previous one cesarean section. J Clin Diagn Res. 2014;8:99-102.

21. Osava RH, Silva FM, Tuesta EF, Oliveira SM, Amaral MC. Cesarean sections in a birth center. Rev Saude Publica. 2011;45:1036-43.

22. Getahun D, Oyelese Y, Salihu HM, Ananth CV. Previous cesarean delivery and risks of placenta previa and placental abruption. Obstet Gynecol. 2006;107:771-8.

23. Alejandro A. Health reform and cesarean sections in the private sector: the experience of peru. Health Policy. 2011;99:124-30.

24. World Health Organization. Estratégia de Cooperação da OMS 2015-2019 Angola. Geneve: WHO; 2016. 